\title{
The Culinary Sector Survival Strategy to Restore Populist Economy Based on the Creative Industry during Covid-19 Pandemic
}

\author{
Mangasi Sinurat ${ }^{\square}$, Lilinesia ${ }^{2}$, M.Subhan ${ }^{3}$, Amsyal Simanjuntak ${ }^{4}$. \\ 1,2Sekolah Tinggi Ilmu Ekonomi Bina Karya Tebing Tinggi, Sumatera Utara,Indonesia, mangasisinurat621@gmail.com, \\ lilinesia@gmail.com \\ ${ }^{3}$ Faculty of Economic and Business Universitas Malikussaleh, Lhokseumawe, Aceh, Indonesia, \\ msubhan@unimal.ac.id \\ 4CV.Express Consulting and Goriset.id (Profesional Reseacrh Planner Academy) Tebing Tinggi, Sumatera \\ Utara,Indonesia , kingkopibecak@gmail.com
}

\begin{abstract}
This study aims to identify and analyze strategies to improve the economic recovery of MSMEs in the culinary sector during the Covid-19 pandemic and when the new normal era was implemented due to the impact of the Covid19 pandemic. The research method used is descriptive qualitative method.The results obtained from this study indicate that there is a need for quick, precise and real steps from the government and business actors to overcome the losses that have occurred due to the pandemic as well as updating and evaluating the business cycle following the current situation. happens so that the business can continue to survive and grow. ). This research was conducted in the culinary center of North Sumatra Province. Data collection was carried out by means of observation, interviews and documentation with purposive sampling technique where informants were selected based on the needs of the researcher with the Snow ball sampling technique, where if the informant could not explain the intended information, further informants would be searched for. The data used in this study are observational data consisting of primary data and secondary data, after observing the data that has been collected then the data is analyzed which is connected with the theory used in this study, then draw conclusions and suggestions can be run by MSMEs and policy makers. From this research process, the population in this study is the culinary business in the province of North Sumatra, which is located in the city of Medan. Then after interviewing one by one the culinary businesses in Medan with the snow ball technique, 30 culinary businesses in Medan were taken as the research object. This pandemic condition has significantly affected the decline in the activities of Micro, Small and Medium Enterprises (MSMEs), especially those in the culinary sector who have to face a situation of decreasing sales quantity, so that culinary MSME players must prepare a strategy so that their business can survive, namely by marketing through social media. in the form of Instagram, Facebook, WhatsApp, collaborating with online transportation service providers such as gofood, grabfood and local couriers, innovating culinary products needed by the community during the pandemic, as well as building and increasing customer trust.
\end{abstract}

\section{Keywords: P2E LIPI, MSME and Covid-19}

\section{Introduction}

Micro, Small and Medium Enterprises or MSMEs in the Culinary Sector are included in the types of productive businesses which up to now their development in Indonesia is classified as very fast. Until now, the culinary sector MSMEs recorded in Indonesia have reached 21.6 million units of the culinary sector and 70.9 million units consisting of; agriculture, livestock, processing, trade, services and communications. In Indonesia, MSMEs have a strategic role and a great influence on the development of the National economy with a total of 54,194,057 in 2018 employing around 116,978,631 workers (Hardilawati, 2020). The contribution of MSMEs to GDP in 2012 was recorded at 59.08\% and until 2018 it reached $60 \%$, the total contribution was an accumulation originating from all sectors of the MSME economy, especially the culinary sector (LPPI Cooperation with Bank Indonesia, 2015, p. 9). Therefore, it can be said that MSMEs are agents capable of bringing about continuous change in society because they are able to help advance and bring innovation and increase creativity (Dhewanto et al, 2015).

The very rapid development of MSMEs in Indonesia is supported by the optimal use of technology, information and communication facilities. However, behind that, there are also factors that hinder the development of a business, as stated by Kuncoro (Setyanto. 2015) which states about factors that hinder the development of a business more specifically, namely; First, it is difficult to get market opportunities and expand market share. Second, it is difficult to get capital due to limited sources of adequate capital. Third, lack of understanding in the field of organization and HR management. Fourth, the lack of breadth of cooperation partners among entrepreneurs. Fifth, unhealthy competition between entrepreneurs. Sixth, the coaching and training that is carried out is still not integrated and there is a lack of public awareness and trust in the existence of small businesses.

Amid the increasingly rapid development of MSMEs in the culinary sector, its movement has decreased due to the emergence of Covid-19 in 2020, which has a direct impact on economic turnover, especially for MSMEs. This global 
pandemic has caused economic instability, especially for MSME players in the creative industry culinary sector who felt the direct impact of a decrease in sales turnover due to the government's appeal to implement large-scale social restrictions (PSBB) which urged people to stay at home so that many MSMEs had to stop for a while. (Hardilawati, 2020). The limited movement of people during the pandemic has resulted in a decrease in sales due to reduced demand, so that MSME players also experience a decrease in turnover.

Modeling to find out the daily increase in case of coronavirus has become a hot topic lately. There are thousands of cases of coronavirus increased in Indonesia and the fluctuating value from day to day. Therefore, one of the techniques often used to solve predictive problems is modeling the Covid-19 case using machine learning techniques by Mandayam et all (2020) and maybe same research make by Gambhir et all (2020) using supervised machine learning techniques with the Regression method. Then research by Jarndal et all (2020) using Artificial Neural Network (ANN) method. The error rate of prediction model is usually assessed by Mean Squared Error (MSE), Root Mean Squared Error (RMSE) or Mean Absolute Error (MAE) (Sulasikim et all, 2020). The ANN and Regression methods still produce thousands of MSE values due to data fluctuation for the increased case of thousands of domains. The data on the thousands increase of fluctuating Covid-19 needs to use a new predictive modeling process approach.

It is very important to conduct research on the role of MSMEs in supporting the Indonesian economy amid the Covid-19 pandemic because Micro, Small and Medium Enterprises (MSMEs) have a strategic role in supporting national economic growth after the impact of the Covid-19 pandemic. This can be seen from the contribution of MSMEs to Indonesia's GDP which continues to increase by around $60 \%$ in the pre-pandemic period. The absorption of labor by MSMEs is also very high and continues to grow, reaching $96.99 \%-97.22 \%$ with the number of MSMEs reaching 62 million or around $98 \%$ of national business actors.

MSMEs can be at the forefront of achieving the economic pillars of the SDGs by creating jobs, creating decent working conditions, business innovation, adapting and mitigating negative economic, social and environmental impacts on business operations for inclusive and sustainable economic growth. To achieve that, collective action from various sectors is needed to support the revival of MSMEs. In this case, the business sector has the ability to find solutions through technology, innovation and investment. The business sector can also play a role in addressing negative environmental and social impacts through the value chains and supply chains of their business operations. Until now, the business sector has also taken part in developing MSMEs for the achievement of SDGs.

One of the MSMEs that never dies is a culinary business because in terms of culinary, it is a processed product in the form of cuisine. These dishes are in the form of side dishes, food, and drinks that are processed in such a way that they become food or drinks that can be enjoyed as food ingredients that are used for the development of the human body, so this culinary business will still be needed as long as humans need food, but this culinary business also experiences decline, this is partly due to the global pandemic.

According to a survey from Bank Indonesia, as many as 62.5 percent of micro, small and medium enterprises (MSMEs), especially the culinary sector, are experiencing pressure due to the Covid 19 pandemic (Sandy, 2020). that of the 262,291 micro, small and medium enterprises in North Sumatra, there are around 22,000 MSMEs, among which have collapsed due to Covid (Jati, 2020). Then based on data processed by P2E LIPI, the impact of the decline in tourism on MSMEs engaged in micro food and beverage businesses reached $37 \%$, while the impact on small food and beverage businesses was $2.77 \%$ and medium enterprises by $1.07 \%$. From the three data that have been mentioned, the Covid 19 pandemic has a very influential in reducing the development of MSMEs, especially in the culinary sector, so a strategy is needed that must be done in order to minimize this decline.

Like culinary tours in general, culinary delights in North Sumatra in particular offer unique dishes that are rarely found in other regions in Indonesia. Most of these culinary delights leave memorable experiences in the hearts of tourists. Indirectly, the charm of culinary tourism is inevitably an important part of an area's identity, especially in promoting the tourism sector in that area.

\section{Literature Review}

Community economic development aims to increase community participation in various development activities, especially in the economic sector. In addition, improving the quality of human resources so that they are able to process natural resources efficiently and sustainably in order to increase income and welfare. Then encourage the community, small and medium entrepreneurs to develop and be able to support the development of the regional economy and create employment and business opportunities.

The populist economy is guided by the fourth principle of Pancasila which can be simply defined that the term democratic economy will contain elements of democracy in it. Democracy that emerges and is extracted from local wisdom. Democracy that characterizes Indonesia is deliberation to reach consensus. Since the Covid-19 pandemic, the Indonesian economy has experienced shocks, one of which is the people's economy. With the existence of various policies related to efforts to prevent the Corona virus, it is difficult for people to carry out economic activities. The Covid19 pandemic has an impact on several business sectors in Indonesia, especially MSMEs.

The Covid-19 pandemic has proven that MSMEs play an important role in the Indonesian economy. The MSME sector is considered to have the highest level of susceptibility to this pandemic because in general, MSMEs earn from daily trade turnover. When MSMEs were no longer able to sustain the economic crisis due to this pandemic, Indonesia's economy fell drastically apart from the impact of the tourism and manufacturing industries. There are several strategies or efforts that can be made by MSME business actors to restore their economy, as revealed by Asmini in her research which describes Business Cycle management which is used as a basis for finding business opportunities after the Covid- 
19 pandemic which then creates an appropriate recovery strategy in the economy. community (Asmini et alL, 2020). In contrast to the research conducted by Hardilawati, Hardilawati suggested strategies that can be carried out by MSMEs to survive are by trading online or by e-commerce, starting to do promotions digitally, and establishing and optimizing customer marketing relationships (Hardilawati, 2020). Meanwhile, according to Setyano et all (2015) who have conducted research on efforts to improve the economy of MSMEs before the Covid-19 pandemic, stated that the strategy for developing MSME Batik Laweyan in improving the economy is to innovate, update products and start implementing social capital by how to expand a business network.

The role of Micro, Small and Medium Enterprises (MSMEs) has an important role in economic development and growth, not only in developing countries (NSB), but also in developed countries (NM). In developed countries, MSMEs are very important, not only that these business groups absorb the most workers compared to large enterprises (UB). As is the case in developing countries, but also its contribution to the formation or growth of gross domestic product (GDP) is greater than the contribution of large businesses.

Small businesses in Indonesia have great potential to be developed because of the wide market, readily available raw materials and large human resources which are the supporting variables for the development of these small businesses, but several things need to be considered along with the development of small-home businesses such as: business development must be followed by good management, good planning will minimize failures, mastery of science will support the sustainability of the business, manage an efficient and effective production system, and make breakthroughs and innovations that make differentiation from competitors a step towards success in managing the business.

Based on research conducted in april 2020 by the ministry of cooperatives and small and medium enterprises, the covid-19 pandemic resulted in 56\% of msmes experiencing a decrease in sales turnover, $22 \%$ experiencing difficulties in obtaining financing or credit, $15 \%$ experiencing problems in the distribution of goods, and $4 \%$ the rest had difficulty getting raw materials. Of all the msmes recorded in this research, the composition of msmes engaged in the micro industry is $87.4 \%$. This figure shows a fact that is higher than that reported by bank indonesia, which is $72.6 \%$ and lower than that reported by lipi, which is $94.7 \%$. The last two researches were conducted in june 2020, the end of the second quarter of 2020. The existence of a large-scale social distancing policy and social distancing can directly hinder msmes in distribution activities, causing a decrease in sales turnover from msmes. Based on data from bank indonesia, msme exporters are the sector most affected, namely around $95.4 \%$ of total exporters. Msmes engaged in the handicraft sector and tourism support were affected by $89.9 \%$. Meanwhile, the sector that was least affected by the covid-19 pandemic was the agricultural sector, which amounted to $41.5 \%$. In addition, based on research data from the ministry of cooperatives and smes, the highest msmes affected by the covid-19 pandemic were $40.92 \%$, namely wholesalers and retailers. The second is msmes providing accommodation, food and beverage as much as $26.86 \%$ and the smallest affected is the processing industry as much as $14.25 \%$.

\section{Materials \& Methods}

This study uses qualitative research methods, qualitative research is a research method used to express human perceptions (Sugiyono, 2014). According to Bogdan and Taylor, qualitative research is a research procedure that produces descriptive data in the form of written or spoken words from people and observable behavior (Bogdan \& Taylor in Moleong, 2007). This research was conducted in the culinary center of North Sumatra Province. Data collection was carried out by means of observation, interviews and documentation with purposive sampling technique where informants were selected based on the needs of the researcher with the Snow ball sampling technique, where if the informant could not explain the intended information, further informants would be searched for. The data used in this study are observational data consisting of primary data and secondary data, after observing the data that has been collected then the data is analyzed which is connected with the theory used in this study, then draw conclusions and suggestions can be run by MSMEs and policy makers.

This study uses a snow ball sample technique. Taking a number of cases through the linkages of one person with another person or one case after another, then looking for the next relationship through the same process, so on. Snowball sampling technique is a method for identifying, selecting and take samples in a network or a continuous chain of relationships. The researcher presents a network through a sociogram image in the form of a circle image that is linked or connected by lines. Each circle represents one respondent or case, and lines shows the relationship between respondents or between cases (Neuman, 2003). Other opinions say that the snowball sampling technique (snowball) is a sampling method in which the sample is obtained through a rolling process from one respondent to another, This method is usually used to explain the social or communication patterns (sociometric) of a particular community. From this research process, the population in this study is the culinary business in the province of North Sumatra, which is located in the city of Medan. Then after interviewing one by one the culinary businesses in Medan with the snow ball technique, 30 culinary businesses in Medan were taken as the research object.

\section{Result and Discussion}

Based on the results of the research, there are four strategies that must be carried out by MSME actors in the culinary sector in order to survive and be able to restore the economy, including the following:

1) Marketing Through Social Media 
In the midst of the current global pandemic along with the state of the world welcoming the presence of a period of advanced technology known as the era of the industrial revolution 4.0, in this era technology is projected to dominate all aspects of human life, including the business world (Purwandini, 2018), this is marked With changes in people's access to information changing from conventional media such as television, newspapers and radio to social media (medsos), this is also due to the price of communication tools in the form of mobile phones / gadgets that are affordable for the middle to lower class and currently the average mobile phone technology Andorid-based, so that almost all levels of society are able to have a cellphone or gadget that is connected to internet access. This convenience makes people have many types of social media in the virtual world in the form of Facebook, Instagram and WhatsApp, YouTube, Twitter (Kurniawan, 2017).

From the changes in the way people access information, it also changes the choices of SMEs in marketing culinary MSME products, which indeed marketing efforts through social media have appeared before the pandemic, so that at the time of the pandemic, marketing using social media networks was increasingly prioritized, marketing channels using social media were usually UMKM players upload products, order procedures, product composition and prices. This method of marketing is easier and more cost-effective, because it does not have to provide advertising costs if it is marketed on conventional media so that it does not increase the variable costs of marketing in producing a culinary product.

2) With changes in marketing patterns through social media

MSME players are required to always learn and innovate and be willing to learn with new technological developments that are increasingly developing. Of course, digital marketing also considers using suitable media and the right way of communication that is tailored to the selected segment or market share (Sugiarti et al., 2020). So that marketing will be more effective and not wrong target.

3) Collaboration with Online Transportation

In addition to marketing MSME products to customers, which is also important for MSME players to do is to facilitate the distribution process of these culinary products if they have been ordered by customers, the policy to stop the spread of the corona virus during the pandemic issued by the government related to social and physical restrictions makes community mobilization to a minimum possible. This policy results in the process of purchasing culinary products also needing to use new methods, previously customers could directly buy and take orders themselves but currently cannot directly, the right choice is to use online transportation services and offline couriers provided by business actors Usually, the culinary sector MSME players have collaborated with online transportation providers such as go-food, grab-food, and local couriers.

4) Culinary Production Innovations

In terms of market segmentation, culinary products have a diverse market share because all age levels require food, both in terms of composition of nutritional value and form. In this pandemic condition, business actors are required to have the ability to innovate and adapt to consumer tastes and demands is very important. In the midst of the threat of spreading the virus, the government health policy strongly encourages the public to strengthen their respective antibodies, which in turn also makes many people and companies aggressively promote the importance of eating healthy foods, especially those that can increase immunity (Koesno, 2020).

Several culinary innovation products that emerged as alternative choices in pandemic conditions were presented by the MSME manager, for example for drinks and food that added flavors of red ginger, lemon, lime, drinks processed with ginger and various types of coffee drinks which were added with ingredients that contained ingredients. substances can increase endurance, while in snacks in the form of foods containing immune enhancing substances, for example by adding variants of raw materials such as ginger, turmeric and ginger. The compounds contained in this type of rhizome are empirically and scientifically recognized to have good effects on health, including being able to increase endurance. In addition, there are even many studies that show the active compounds in these rhizomes have specific activities, such as antioxidants, anti-microbes and anti-viruses (Muhammad, 2020).

From the information presented, it shows the efforts made by culinary entrepreneurs by adding certain types of food ingredients that can increase endurance, is a form of innovation that can be used as a strategy by MSME players so that their business activities can survive amid a pandemic, in addition to their business activities continuing also in line with efforts to help people get healthy food and food to increase endurance.

5) Maintain Customer Trust

As a basic requirement, this culinary product has customers or consumers who are loyal to products who always maintain a stable quality of taste and price. So it is important for MSME players in this sector to maintain and maintain good relationships with their consumers by creating and maintaining customer satisfaction which will ultimately create customer loyalty to marketed culinary products (Hardilawati, 2020). Loyal consumers will not switch to other culinary products because they already have confidence in our culinary products. One way for culinary MSMEs to survive amid the decline in business activity is to strengthen consumer confidence

Rukmana \& Sukanta stated in their research that MSME business actors can choose two alternative options to avoid stopping production activities, namely increasing the selling price of products while maintaining quality or not increasing product prices provided the quality of the products provided is decreasing from the previous ones. This is also related to the availability of raw materials for certain products which are increasingly scarce due to the high 
demand for certain products, so entrepreneurs must have the courage to take the risk of choosing these two options. Other solutions that can be carried out by MSME players are: first, it is necessary to have integrated management of product stocks to monitor inventory of goods, second to monitor merchandise shipments both inside and outside the city, third to seek fast communication to customers even through social media, fourth, seek to use a payment system via bank transfer or electronic payment. (Arif, 2020).

Table 1. Internal Strategy Factors SWOT Analysis of the Creative Industry in the Culinary Sector in North Sumatra

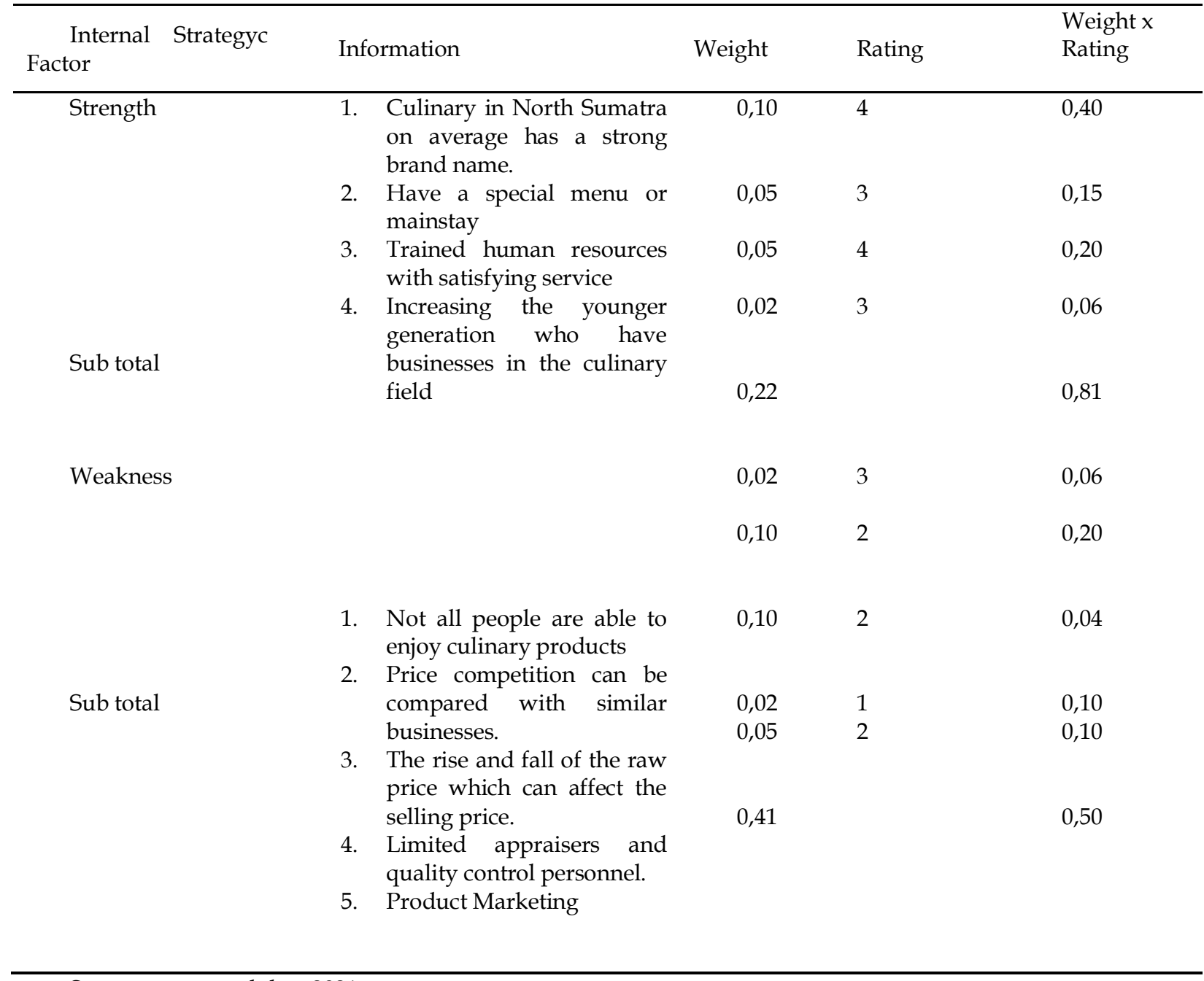

Source : processed data 2021

Table 2. External Strategy Factors SWOT Analysis of the Creative Industry in the Culinary Sector in North Sumatra 


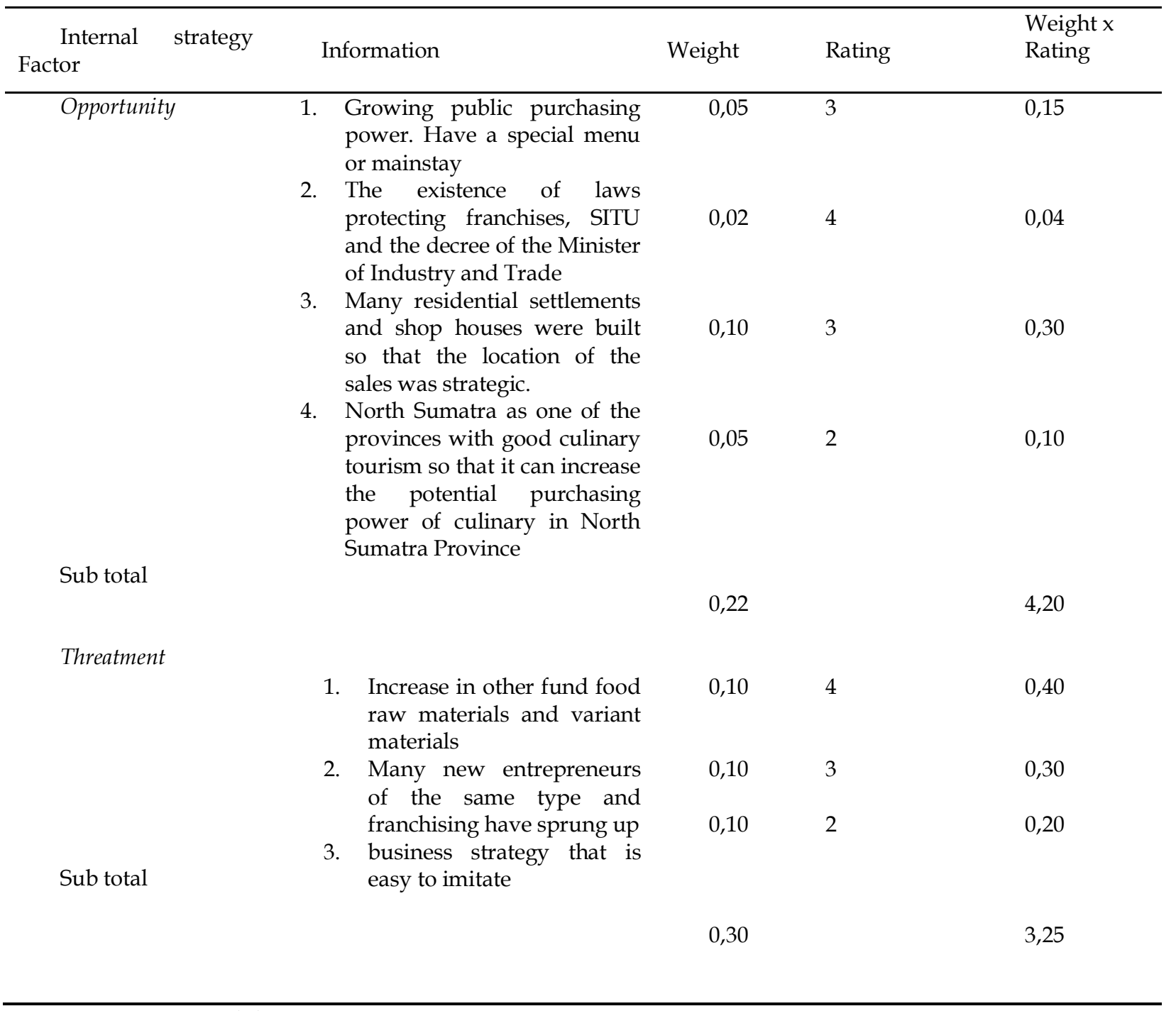

Source : processed data 2021

After weighting and determining the strategy which is determined by a combination of internal and external factors, the main strategy will be determined with a swot analysis, swot analysis compares the external factors, opportunities and threats with internal factors of strengths and weaknesses (weaknesses).

\section{Conslusion}

This pandemic condition has significantly affected the decline in the activities of Micro, Small and Medium Enterprises (MSMEs), especially those in the culinary sector who have to face a situation of decreasing sales quantity, so that culinary MSME players must prepare a strategy so that their business can survive, namely by marketing through social media. in the form of Instagram, Facebook, WhatsApp, collaborating with online transportation service providers such as gofood, grabfood and local couriers, innovating culinary products needed by the community during the pandemic, as well as building and increasing customer trust.

The solution that can be submitted by the author is for the culinary sector MSME actors to be able to maintain existing strategies and adopt new innovations due to the demands of changes and conditions, while for policy makers to provide assistance and training related to strategies and innovations needed by the culinary sector MSME actors. this so it can survive even in the conditions.

Then the strategies that can be carried out by business actors include serving consumers through online platforms, increasing total quality management related to hygiene, and changing temporary business methods so that financial reports remain positive. In addition, the government provides social assistance and tax incentives, credit restructuring and relaxation, and expansion of capital financing for MSMEs.

MSME entrepreneurs in the city of Medan hope that a more capable community, philanthropists, companies that have CSR programs must move endlessly to provide support to the community, and if they are able, they must help the government. All MSME business actors in the city of Medan will work hand in hand to be strong against the pandemic, the community must also be able to follow the stay at home policy. Until now, many people have seen people leaving the house, even making time to hang out. This of course will make it difficult for the government to break the chain of spreading corona. 
There is a budget of Rp. 100 billion from the Pemko Medan and 18 billion from the North Sumatra Provincial Government. It seems difficult to say that these funds are sufficient to subsidize entrepreneurs, because of course there are top priorities that must take precedence such as medical personnel and handling of corona cases, and vulnerable communities. But what is certain is that government funds are expected to help with the right target. This research only focuses on MSMEs in the city of Medan, North Sumatra province, and still only explores the survival strategy of the culinary business. This of course cannot be considered to represent all MSMEs in Medan City, North Sumatra Province because it does not cover all MSME business sectors. It is hoped that future research can focus on the wider MSME sector, then it must be able to represent the state of MSME business in the city of Medan, North Sumatra province or even if it has the support and time it is recommended to research the MSME business sector which is more widespread throughout the region. Indonesia.

\section{Acknowledgments}

Thank's a lot to Dr. Rico Nur Ilham, SE., MM.RSA as the owner of CV.Express Consulting who has facilitated the process of publishing this scientific article and also especially to the journal management at Malikussaleh University who is willing to cooperate in the process of publishing articles about The Culinary Sector MSME Survival Strategy in Effort to Restore Populist Economy Based on the Creative Industry during the Covid-19 Pandemic.

\section{References}

Asmini, Sutama, I. N., Haryadi, W., \& Rachman, R. (2020). Manajemen Business Cycle Sebagai Basis Peluang Usaha Pasca Covid-19: suatu Strategi Pemulihan Ekonomi Masyarakat. Indonesian Journal of Social Sciences and Humanities, 1(2), 121-129.

Arif, N. (2020). Strategi UMKM Dalam Menghadapi New Normal . Dipetik 2020, dari Suara.com: https:/ / www.suara.com/yoursay/strateg i-umkm-dalam-menghadapi-newnormal.

Dhewanto, W. (2015). Entrepreneurship training for community in rural area: motivation and knowledge of entrepreneurship. Advanced Science Letters, 21 (6), 1858-1862.

Dian Amintapratiwi Purwandini, I. (2018). Komunikasi Korporasi Pada Era Industri 4.0. Jurnal Ilmu Sosial, 17(1), $53-63$.

Gambhir, E., Jain, R., Gupta, A. \& Tomer, U. (2020). Regression Analysis of COVID-19 Using Machine Learning Algorithms. Proceedings of the International Conference on Smart Electronics and Communication (ICOSEC 2020), pp. 65-71. https:// doi.org/10.1201/9781351073974.

Hardilawati, W. L. (2020, Juni 1). Strategi Bertahan UMKM di Tengah Pandemi Covid-19. Jurnal Akuntansi E Ekonomika, 10(1), 90-98.

Ilham, Rico.N et all (2019). Investigation of the Bitcoin Effects on the Country Revenues via Virtual Tax Transactions for Purchasing Management. International Journal of Suplly Chain Management.Volume 8 No.6 December 2019.

Ilham, Rico.N et al. (2019). Comparative of the Supply Chain and Block Chains to Increase the Country Revenues via Virtual Tax Transactions and Replacing Future of Money. International Journal of Suplly Chain Management.Volume 8 No.5 August 2019.

Jarndal, A., Husain, S., Zaatar, O., Gumaei, T.A.\& Hamadeh, A. (2020). GPR and ANN based Prediction Models for COVID-19 Death Cases. 2020 International Conference on Communications, Computing, Cybersecurity, and Informatics (CCCI), pp. 1-5. https://doi.org/10.1109/ccci49893.2020.9256564.

Jati, R. P. (2020). Sebanyak 12.000 UMKM di Sumsel Terpuruk akibat Pandemi. Kompas. https://kompas.id/baca/nusantara/2020/08/25/seban yak-12-000-umkm-di-sumsel-terpuruk-akibatpandemi/

Kerjasama LPPI dengan Bank Indonesia. (2015). Profil Bisnis Usaha Mikro, Kecil dan Mengengah (UMKM) (PBI No.17/12/PBI/2015). Retrieved from https://www.bi.go.id/

Koesno, D. A. S. (2020). Survei: Kebiasaan Makan Orang Berubah Akibat Pandemi COVID-19. Tirto.Id. https:/ / tirto.id/survei-kebiasaan-makanorang-berubah-akibat-pandemi-covid-19-fulC.

Kurniawan, P. (2017). Pemanfaatan Media Sosial Instagram Sebagai Komunikasi Pemasaran Modern Pada Batik Burneh Jurnal Kompetensi, 11(2), 217- 225.

Mandayam, A.U., C, R. A., Siddesha, S. \& Niranjan, S.K. (2020). Prediction of Covid-19 Pandemic Based on Regression. Fifth International Conference on Research in Computational Intelligence and Communication Networks (ICRCICN), pp.1-5.

Moleong, L. J. (2007). Metode Penelitian Kuantitatif. Remaja Rosdakarya.

Muhammad, D. R. A. (2020). Pola Makan Sehat dan Bergizi untuk Meningkatkan Imunitas saat Terserang Covid-19. Uns.Ac.Id. https://uns.ac.id/id/uns-opinion/pola-makan-sehatdan-bergizi-untuk-meningkatkan-imunitassaatterserang-covid-19.html

Sadalia, I, Syahyunan dan Butar-Butar, N A. 2017. “Financial Behavior and Performance on Small and Medium Enterprises in Coastal Area of Medan City", IOP Conf. Series Materials Science and Engineering 180 (2017) 012257. Medan.

Sandy, K. F. (2020). Survei BI: 72,6 Persen UMKM Turun Omzet akibat Pandemi Covid-19. Inews.Com.IdFinance.https://www.inews.id/financ e/makro/survei-bi-726-persen-umkm-turun-omzetakibatpandemi-covid-19.

Setyanto, A. R., Samodra, N. R., \& Pratama, Y. P. (2015, Oktober). Kajian Strategi Pemberdayaan UMKM dalam Menghadapi Perdagangan Bebas Kawasan ASEAN (Studi Kasus Kampung Batik Laweyan). Etikonomi, 14(2), 205220.

Sugiarti, Y., Sari, Y., \& Hadiyat, M. A. (2020). ECommerce untuk Meningkatkan Daya Saing Usaha Mikro Kecil dan 
Menengah (UMKM) Sambal di Jawa Timur. Kumawula: Jurnal Pengabdian Kepada Masyarakat, 3(2), 298. https://doi.org/10.24198/kumawula.v3i2.28181.

Sugiyono. (2014). Memahami Penelitian Kualitatif. Bandung: Alfabeta.

Sulasikin, A., Nugraha, Y., Kanggrawan, J. \& Suherman, A.L. (2020). Forecasting for a Data-Driven Policy Using Time Series Methods in Handling COVID-19 Pandemic in Jakarta. 2020 IEEE International Smart Cities Conference (ISC2), pp. 1-6. https://doi.org/10.2139/ssrn.3714105. 